\title{
Preliminary Study of Alkaline Direct Ethanol Fuel Cell by Using Crosslinked Quaternized Poly (Vinyl Alcohol)/Graphene Oxide Membrane
}

(Kajian Awal Sel Fuel Etanol Langsung Beralkali Menggunakan Membran Elektrolit Berasaskan Alkohol Polivinil Terkuaternisasi/Grafin Oksida)

\author{
Zulfirdaus Zakaria* \& Norazuwana Shaari \\ Institute of Fuel Cell, Universiti Kebangsaan Malaysia, Malaysia \\ Siti Kartom Kamarudin \\ Institute of Fuel Cell, Universiti Kebangsaan Malaysia, Malaysia \\ Faculty of Engineering \& Built Environment, Universiti Kebangsaan Malaysia, Malaysia
}

\begin{abstract}
A crosslinked of Quaternized Poly (vinyl alcohol)/Graphene oxide (QPVA/GO) composite membrane was prepared via quaternization and solution casting method. With the main objective is to performed lower ethanol permeability membrane than Nafion 117 membrane thus can be the potential alternative membrane in future. The physical and chemical properties of the QPVA/GO membrane were investigated via the Fourier Transform Infrared Spectroscopy (FTIR), X-ray diffraction analysis (XRD) and Filed Emission Scanning Electron Microscopy (FESEM). The characterization result shows the good interaction of matrix polymer, Go loading and glutaraldehyde as a crosslinked agent. A maximum conductivity of $1.08 \times$ $10^{-2} \mathrm{~S} \mathrm{~cm}^{-1}$ was obtained for QPVA $/ 10 w t \%$ GO membrane at $30^{\circ} \mathrm{C}$. The ethanol permeability has been reduced until $2.2 \times$ $10^{-7} \mathrm{~cm}^{2} \mathrm{~s}^{-1}$ with increasing of $10 \mathrm{wt} . \%$ GO loading which was lower than Nafion $117\left(19.5 \times 10^{-7} \mathrm{~cm}^{2} \mathrm{~s}^{-1}\right)$. The increasing of GO content in composite membranes has append the hydrophobic region which play role as blocking effect to hinder the ethanol crossover. The cell voltage and power density were analyzed at the temperature $30^{\circ} \mathrm{C}$. A maximum power density achieved by QPVA/GO membrane was $6.92 \mathrm{~mW} \mathrm{~cm}^{-2}$ at 10.wt\% GO loading which higher than Nafion 117 with only $5.07 \mathrm{~mW}$ $\mathrm{cm}^{-2}$ using $2 \mathrm{M}$ ethanol $+2 \mathrm{M} \mathrm{KOH}$ at $30^{\circ} \mathrm{C}$.
\end{abstract}

Keywords: Quaternized Poly (vinyl alcohol); Graphene oxide, alkaline-DEFC; Nafion 117

ABSTRAK

Membran komposit alkohol polivinil terkuaternisasi/grafin oksida terpaut silang telah disediakan menerusi proses kuaternisasi dan kaedah tebaran pelarut. Dengan objektif utama kajian untuk menghasilkan membran yang mempunyai kebolehtelapan etanol yang lebih rendah berbanding membran Nafion yang mana akan menjadikan membran ini berpotensi untuk menjadi membran alternatif pada masa hadapan. Sifat-sifat fizikal dan kimia membran QPVA/GO telah dikaji menggunakan spektroskopi inframerah transformasian Fourier, pembelauan sinar-X dan Mikroskop Elektron Imbasan Medan Pancaran. Kekonduksian maksimum yang dihasilkan oleh membran QPVA/GO 10 wt.\% ialah $1.08 \times 10^{-2} \mathrm{~S} \mathrm{~cm}^{-1}$ pada suhu $30^{\circ} \mathrm{C}$. Kebolehtelapan etanol pula berkurang sehingga $2.2 \times 10^{-7} \mathrm{~cm}^{2} \mathrm{~s}^{-1}$ dengan peningkatan berat pengisi GO sehingga 10wt.\% lebih rendah berbanding Nafion $117\left(19.5 \times 10^{-7} \mathrm{~cm}^{2} \mathrm{~s}^{-1}\right)$. Peningkatan kandungan GO di dalam membran komposit telah menambahkan kawasan hidrofobik yang di mana bahagian ini bertindak sebagai kesan penghadang kepada lintasan etanol. Prestasi sel dan ketumpatan kuasa juga dianalisis pada suhu $30^{\circ} \mathrm{C}$. Ketumpatan kuasa maksimum yang dihasilkan oleh membran PVA/ GO mencapai $6.92 \mathrm{~mW} \mathrm{~cm}^{-2}$ dengan bebanan GO sebanyak $10 \mathrm{wt} \%$ yang mana lebih tinggi berbanding membran Nafion yang hanya mencapai $5.07 \mathrm{~mW} \mathrm{~cm}^{-2}$ dengan menggunakan $2 \mathrm{Metanol}+2 \mathrm{M} \mathrm{KOH}$ pada suhu $30^{\circ} \mathrm{C}$.

Kata kunci: Alkohol polivinil terkuaternisasi; Grafin oksida; DEFC beralkali; Nafion 117

\section{INTRODUCTION}

Ethanol has a potential as an alternative power source due to their advantages compared to methanol as known as pioneer alcohol applied in micro fuel cell technologies. For examples, ethanol has higher volumetric energy density of $8.00 \mathrm{~kW} \mathrm{~h} \mathrm{~kg}^{-1}$ than methanol only $6.09 \mathrm{~kW} \mathrm{~h} \mathrm{~kg}^{-1}$, classified as renewable energy due to its natural availability and can be produced in bulk from agricultural bio-processes and nontoxic, which avoids environmental pollution issues and safe for human (An et al. 2015; Badwal et al. 2015; O'hayre et al. 2016).

Today, passive alkaline direct ethanol fuel cell (alkalineDEFC) is one of direct alcohol fuel cell types gain attention among the researchers. The passive alkaline-DEFC has promise several advantages compared to conventional power sources 
for portable devices such as lower temperature operation, compact, flexible in design of cell, faster rechargeable, easier in storage and transportation (Akhairi \& Kamarudin 2016). Polymer electrolyte membrane is an important part in the fuel cell development. Basically, the function of this part are separating the chemical reaction of ethanol oxidation in anode and reduction oxygen in cathode, barrier for the ethanol crossover, allow the ionic transfer and obstruct the electron diffuse through the polymer electrolyte membrane (Huang et al. 2016; Zakaria et al. 2016). Wang et al. (2010) fabricate poly (vinyl alcohol)/3-(trimethylammonium) propyl functionalized silica (PVA-TMAPS) composite membrane and use in alkaline DEFC system. The membrane with a ratio of PVA: TMAPS $=90: 10$ exhibited the highest $\mathrm{OH}$ conductivity. Zeng et al. (2012) also studied about PVA based membrane in alkaline DEFC which accompanied with layered double hydroxide with maximum power density achieved of $82 \mathrm{~mW}$ $\mathrm{cm}^{-2}$ at $80^{\circ} \mathrm{C}$. Besides, Huang et al. (2016) also fabricated the membrane which applied in DEFC which consist of graphene and CNT as filler in PVA based membrane, respectively.

Nafion membrane is used as polymer electrolyte membrane commonly in direct alcohol fuel cell due to the higher ionic conductivity performance. Unfortunately, this membrane experienced higher fuel permeability leading to the fuel crossover which cause several problems such as loss of ethanol fuel, poisoning the cathode catalyst and degrade the single cell performance. Besides, the production cost of Nafion membrane is expensive which thus limit the commercialization of fuel cell product. Therefore, to develop an alternative membrane that can replace the conventional membrane is the urgent necessary (Zhao et al. 2010; Zakaria et al. 2016; An \& Zhao 2017).

Poly (vinyl alcohol) (PVA) is a particularly interesting and versatile polymer due to low cost, hydrophilic polymer, non-toxic materials, biodegradable and suitable as electrolyte membrane for alkaline-DEFC. Moreover, PVA has high ability in chemical resistance, thermal resistance and high film forming ability. Fortunately, PVA is also low soluble in ethanol that beneficial in reducing the ethanol permeability problem as facing by conventional fuel cell system. On the other hand, PVA has low ionic conductivity and high solution uptake which leading to the swelling problem (Saxena 2004; Zeng et al. 2012). But, the advantages of PVA polymer is high hydrophilicity and availability of free sites for the formation of a stable membrane with good mechanical properties that swelling property can be controlled and thus can be the backbone of the composite membrane (Wang et al. 2010; de Souza Gomes \& Dutra Filho 2012).

In this study, the main focus is to explore the potential of PVA based membrane in passive alkaline-DEFC which success in reducing the ethanol permeability as reported in previous study (Zeng et al. 2012). With introduce the quaternary ammonium function group graft to backbone chain of PVA, the quaternization process will build the new functionalized polymer call as quaternized poly (vinyl alcohol) (QPVA). (Xiong et al. 2008) claimed the membrane based QPVA polymer able to increase the ionic conductivity until $7.35 \times 10^{-3} \mathrm{~S} \mathrm{~cm}^{-1}$ in deionized water. Besides, in order to increase the conductivity of membrane and maintain the ability to reduce ethanol permeability, the QPVA polymer was blended with the Graphene Oxide (GO) inorganic filler as GO has received great attention among researchers due to the interesting characteristic. Therefore, GO is a promising membrane material for fuel cell technologies (Cao et al. 2011; Shaari \& Kamarudin 2017; Farooqui et al. 2018). GO will provide good ionic conductivity due to oxygenic functional group such as hydroxyl, carboxylic, and epoxy groups in the hydrophilic region surrounding of edge GO. Karim et al. (2016) has described the potential of GO that can increase the conductivity of membrane which had achieved nearly $10^{-2}$ $\mathrm{S} \mathrm{cm}^{-1}$ that higher than bulk graphite oxide with only $10^{-4} \mathrm{~S}$ $\mathrm{cm}^{-1}$. Moreover, the hydrophobic region in the GO nano-sheet structure which consists of $\mathrm{sp}^{2}$ carbon layer can contribute in ethanol crossover reduction and improve the mechanical strength of the membrane due to the strong covalent bonding. The objective of this present work is to prepare, characterize and determine the performance of crosslinked quaternized poly (vinyl alcohol)/graphene oxide (assigned as QPVA/GO) composite membrane which is expected can effectively reduce the ethanol permeability and improve the ionic conductivity consequently competent to the commercial Nafion membrane in passive alkaline-DEFC.

\section{METHODOLOGY}

MATERIAL

Poly (vinyl alcohol) (PVA) (Mw 85,000-124,000, $99+\%$ hydrolyzed), graphite powder, sodium nitrate $\left(\mathrm{NaNO}_{3}\right)$, potassium permanganate $\left(\mathrm{KMnO}_{4}\right)$ and glycidyltrimethyl ammonium chloride (GTMAC) were supplied by Sigma Aldrich. Glutaraldehyde (GA, 25\% content in distilled water) provided from Nacalai Tesque/Japan. Potassium hydroxide (KOH), Phosphoric acid $\left(\mathrm{H}_{3} \mathrm{PO}_{4}\right)$, bought from J.T. Baker. $\mathrm{Pt}-\mathrm{Ru}$ and Pt were supplied by Alfa Aesar, USA. All these commercial material are used without any purification.

\section{SYNTHESIS OF QUATERNIZED PVA}

The appropriate amount of PVA was dissolve in deionized water under stirring at $90^{\circ} \mathrm{C}$ for $2 \mathrm{~h}$. The resulting PVA solution became homogeneous, transparent and viscous in appearance. The temperature of viscous solution was reducing to $65^{\circ} \mathrm{C}$. Then, the appropriate amount of GTMAC, $\mathrm{KOH}$ (GTMAC:KOH $=1: 1$ in mole ratio) was introduced and the resulting homogeneous and colorless solution, keep stirring for $4 \mathrm{~h}$. The solution was rinsed off with anhydrous ethanol to obtain yellow precipitates of quaternized poly (vinyl alcohol) (QPVA) followed by drying process in vacuum oven.

SYNTHESIS OF GRAPHENE OXIDE

The Modified Hummers methods was applied to synthesis the graphene oxide (GO) (Leong et al. 2015). $2 \mathrm{~g}$ of graphite is 
mixed with $2 \mathrm{~g}$ of $\mathrm{NaNO}_{3}$ in $500 \mathrm{ml}$ volumetric flask. Then, $150 \mathrm{ml}$ of $\mathrm{H}_{2} \mathrm{SO}_{4}$ is poured and continuous stirring for $30 \mathrm{~min}$ in the ice bath $\left(0-5^{\circ} \mathrm{C}\right)$. After that, the mixture was added with $12 \mathrm{~g}$ of $\mathrm{KMnO}_{4}$ while the reaction temperature should be controlled and maintained below $20^{\circ} \mathrm{C}$ for $4 \mathrm{~h}$. Remove the ice bath and retain stirring until the solution appear liked pasty brownish for one day at $35^{\circ} \mathrm{C}$. Next, the solution was diluted with $100 \mathrm{ml}$ D.I water to form a brown solutions, quickly, the temperature rise until $98^{\circ} \mathrm{C}$. Then, add more 200 $\mathrm{ml}$ of water to reduce the temperature. Lastly, $10 \mathrm{ml}$ of $\mathrm{H}_{2} \mathrm{O}_{2}$ was poured to treat the solution and obviously yellow color performed. The centrifuge used to purified the solution with $10 \% \mathrm{HCl}$ and DI water was used to rinsing which purification step was repeated the for several times.

\section{PREPARATION OF THE CROSS-LINKED QPVA/GO COMPOSITE} MEMBRANE

QPVA (8wt.\%) was dissolve in deionized (DI) water by magnetic stirrer for $1 \mathrm{~h}$ at $75^{\circ} \mathrm{C}$ to form homogenous and transparent solution. GO solution with 2 wt.\%, 4 wt.\%, 6 wt. $\%, 8$ wt. $\%$ and $10 \mathrm{wt} . \%$ was prepared with diluting the GO solution $(1 \mathrm{~g} / \mathrm{L})$ provided. The solution of QPVA was continuously stirring which then mix with various GO solution wt. $\%(2: 1=$ ratio of volume $)$ for $1 \mathrm{~h}$ and then produce QPVA/ GO solution looks like yellow brown color. The yellow brown solution was continuous stirring then followed by addition of $10 \mathrm{wt} . \%$ of GA and stirred for $30 \mathrm{~min}$. The solution was cast onto a plastic plate and permits solvent evaporation at ambient temperature for 24 hours and then dried in a vacuum oven at $60^{\circ} \mathrm{C}$ for 12 hours. The membrane was peeled off from plastic plate and then put on glass plate for annealing process at $100^{\circ} \mathrm{C}$ for 1 hour. Then, the membrane was conducted by immersing the membrane in $1 \mathrm{M}$ of $\mathrm{KOH}$ solution at $80^{\circ} \mathrm{C}$ for 24 hours. The excess of $\mathrm{KOH}$ on the membrane surface was removed by repeatedly rinsing with D.I. water and stored in D.I. water at room temperature for prior use.

\section{CHARACTERIZATION}

FOURIER TRANSFORMATION INFRARED SPECTROSCOPY

Fourier Transformation Infrared spectroscopy (FTIR) analysis of crosslinked QPVA membrane and crosslinked QPVA/GO composite membrane was recorded on Perkin Elmer FTIR spectrophotometer with an ATR (attenuated total reflection) module. The samples were hold in sample holder and placed in the ATR-FTIR system. The FTIR studies were conduct in ambient temperature and the spectral range was 400-4000 $\mathrm{cm}^{-1}$.

$$
\text { X-RAY DIFFRACTION }
$$

X-ray diffraction (XRD) spectrometer (model D8 Advance, Bruker AXs Germany) was used to assess the crystallinity of GO, crosslinked QPVA membrane and crosslinked QPVA/GO composite membranes. Radiation was generated using $\mathrm{Cu} \mathrm{K} \alpha$ (wavelength of $0.15406 \mathrm{~nm}$ ) at anode operating power was $40 \mathrm{kV}$ and $40 \mathrm{~mA}$. The scanning rate was $0.5^{\circ} \mathrm{s}^{-1}$ with a $0.02^{\circ}$ resolution. XRD spectra were recorded over $10^{\circ}-50^{\circ}$.

FIELD EMISSION SCANNING ELECTRON MICROSCOPE

The surface and cross-section morphologies of the crosslinked QPVA membrane and cross-linked QPVA/GO composite membrane was viewed using ZEISS SUPRA 55VP Field Emission Scanning Electron Microscope (FESEM).

$$
\text { PERFORMANCE }
$$

ETHANOL PERMEABILITY

The diffusion cell that consists of two glass compartment was built to measure the ethanol permeability through the membrane. Two compartment glasses was separated as the feed compartment was filled with $2 \mathrm{M}$ ethanol and another side was the receiving chamber which containing of deionized water. Each compartment contained a magnetic stirring bar for solution agitation. All the samples of crosslinked QPVA/ GO composite membrane and Nafion 117 membrane was clamped vertically between two glass compartments. During experiment, the ethanol crossover concentration through membrane was measured with the membrane permeability was calculated by using the following equation (1):

$$
\mathrm{P}=\frac{1}{C a}\left(\frac{\Delta C b(t)}{\Delta t}\right)\left(\frac{L V b}{A}\right)
$$

$\mathrm{P}$ is represent the ethanol diffusion permeability of the membrane $\left(\mathrm{cm}^{2} \mathrm{~s}^{-1}\right), \mathrm{C}_{\mathrm{a}}$ is representing the concentration of feeding chamber in cell $\mathrm{A}\left(\mathrm{mol} \mathrm{L}^{-1}\right), \Delta C b(t) / \Delta t$ is representing the slope of the molar concentration variation of ethanol in cell $\mathrm{B}$ as a function of time $\left(\mathrm{mol} \mathrm{L}^{-1} \mathrm{~s}\right), \mathrm{V}_{\mathrm{b}}$ is representing the volume of each diffusion reservoir $\left(\mathrm{cm}^{3}\right)$, $\mathrm{A}$ is representing the membrane area and $\mathrm{L}$ is representing the thickness of the membrane $(\mathrm{cm})$. The ethanol concentration in cell B is calculated from refractometer. The dropwise of solution is taken from second compartment at certain range of time and drop on refractometer. The refractometer than give index of refraction for that ethanol solution to be used in determination of ethanol concentration.

\section{IONIC CONDUCTIVITY}

The ionic conductivity measurement was determined via using an electrode system, which contained a four stainless steel electrodes connected to an impedance analyzer WonATech potentiostat (WMPG1000). The crosslinked QPVA/ GO composite membrane were equilibrate in deionized water and conducted at ambient temperature. The membrans were laid in transverse direction and sandwiched by stainless steel electrodes. All measurement was carried out using the equation (2):

$$
\sigma=\frac{L}{R S}
$$


Where $\sigma, \mathrm{L}, \mathrm{R}$ and $\mathrm{S}$ are represent the proton conductivity $\left(\mathrm{S} \mathrm{cm}^{-1}\right)$, distance between the counter electrodes $(\mathrm{cm})$, ohmic resistance of the membranes $\left(\mathrm{S}^{-1}\right)$ and cross section area of the membrane samples $\left(\mathrm{cm}^{2}\right)$.

\section{SELECTIVITY FACTOR}

The selectivity factor of the crosslinked QPVA/GO composite membrane (the ratio of the proton conductivity to the ethanol permeability) was determined using this following equation (3):

$$
\text { Selectivity, } \Phi=\frac{\sigma}{P}
$$

PERFORMANCE OF PASSIVE ALKALINE - DEFC

The membrane - electrode assembly (MEA) for passive alkaline-DEFC test cell was fabricated by sandwich the crosslinked QPVA/GO composite membrane between anode and cathode electrodes via hot-pressing machine. For anode, a Pt-Ru catalyst applied was $4 \mathrm{mg} \mathrm{cm}^{-2}$ loading and cathode was applied by Pt catalyst with $4 \mathrm{mg} \mathrm{cm}^{-2}$ loading which carbon paper act as gas diffusion layer via manual casting technique. DEFC performance was tested through a passive air-breathing with homemade single cell stack which active area of MEA is $4 \mathrm{~cm}^{2}$. The fuel reservoir region of the single cell stack allows fulfilling by $2 \mathrm{~mL}$ of fuel. The polarization data were obtained using the potentiostat/galvanostat (WonATech) to measure the voltage response by applying load current for the single cell at ambient condition. $2 \mathrm{M} \mathrm{KOH}+2 \mathrm{M}$ ethanol react as fuel in anode and air diffuse surrounding in cathode.

\section{RESULTS AND DISCUSSION}

CHARACTERIZATION OF QPVA AND CROSSLINKED QPVA/GO COMPOSITE MEMBRANE

Figure 1 indicate the FTIR spectra of QPVA and crosslinked QPVA/GO composite membrane from $400 \mathrm{~cm}^{-1}$ to 3900 $\mathrm{cm}^{-1}$ wavelength. For the crosslinked QPVA membrane, the absorption peak appear at $686 \mathrm{~cm}^{-1}, 1643 \mathrm{~cm}^{-1}$ and 3399 $\mathrm{cm}^{-1}$ which belongs to the aliphatic $\mathrm{C}-\mathrm{H}$ bending, $\mathrm{C}=\mathrm{C}$ from backbone from matrix polymer and group of hydroxyl (Gu et al. 2008; Han et al. 2011); at $968 \mathrm{~cm}^{-1}$ belongs to characteristic of aliphatic of $\mathrm{C}-\mathrm{N}$, it is indicate that the quaternary ammonium group was grafted onto the backbone of matrix polymer of QPVA (Xiong et al. 2008); at $1115 \mathrm{~cm}^{-1}$ is indicate the $\mathrm{C}-\mathrm{O}-\mathrm{C}$ stretch group appeared after the crosslinking treatment and it proved that the cross-linking reaction by GA was successful (Wang et al. 2010). After modification of matrix polymer of QPVA with GO, all the peak of matrix polymer reduce due to interaction of hydrogen bonding with the GO. The several peak of oxygenic functional group from GO loading are appear in composite membrane, at $1351 \mathrm{~cm}^{-1}$ is belongs to epoxy $\mathrm{C}-\mathrm{O}$ symmetric vibrations ( $\mathrm{Lin}$ et al. 2017); $1460 \mathrm{~cm}^{-1}$ is represent the stretching vibration from $\mathrm{O}=\mathrm{C}-\mathrm{O}$ group ( $\mathrm{Lin} \& \mathrm{Lu} 2013$ ); $1656 \mathrm{~cm}^{-1}$ is attributed to the $\mathrm{C}=\mathrm{C}$ stretch from aromatic structure corresponding to $\mathrm{sp}^{2}$ characteristic of GO hydrophobic region (Han et al. 2011); $1720 \mathrm{~cm}^{-1}$ singed from - $\mathrm{COOH}$ stretching carboxylic group.

The peaks appear at wavelength of $2871 \mathrm{~cm}^{-1}$ were attributed to the $=\mathrm{C}-\mathrm{H}$ stretching vibration and the strong and broad absorption at $3399 \mathrm{~cm}^{-1}$ of $-\mathrm{OH}$ hydroxyl functional group stretching vibration (Lo et al. 2013). The peak for the cross-linking GA treatment effect can be seen appear at $1115 \mathrm{~cm}^{-1}$ that belongs to the $\mathrm{C}-\mathrm{O}-\mathrm{C}$ stretch group thus proved that the cross-linking reaction by GA was successful occurred (Wang et al. 2010). From the FTIR spectra analysis,

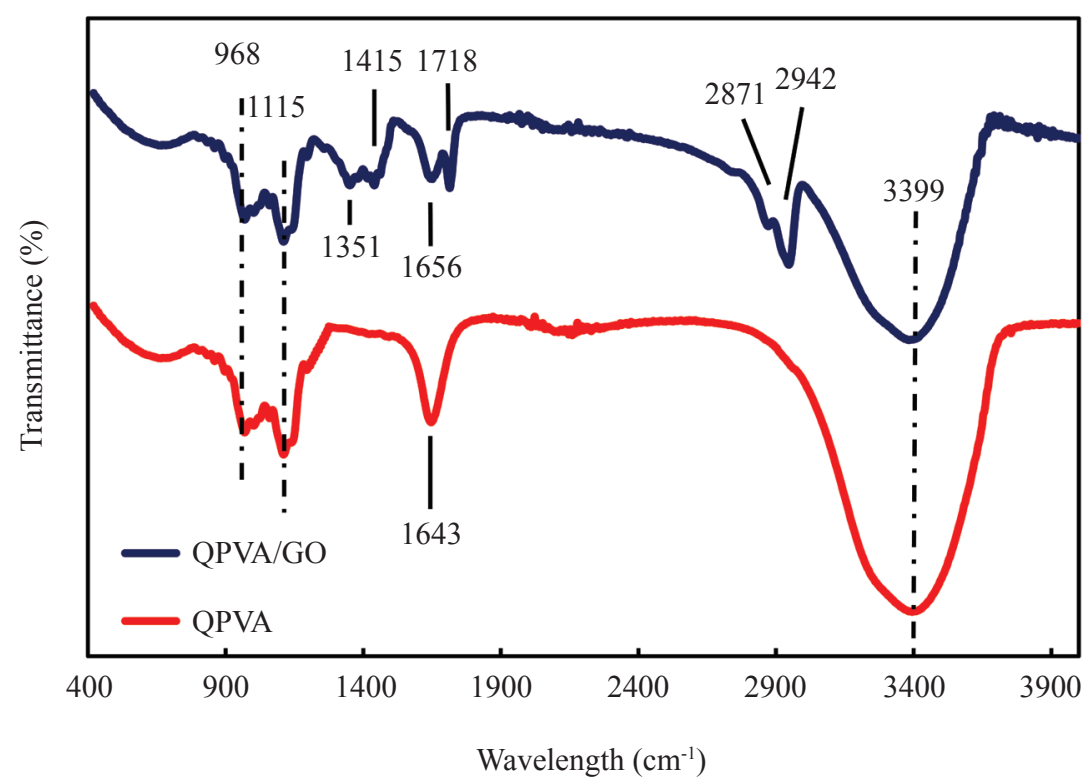

FIGURE 1. FTIR spectra of crosslinked QPVA membrane and crosslinked QPVA/GO composite membrane 
the peak of crosslinked QPVA membrane and crosslinked QPVA/GO composite membrane obviously demonstrate similar functional group as reported in previous work (Xiong et al. 2008; Lo et al. 2013; Lee et al. 2014);

$\mathrm{X}$-ray diffraction was perform to observe the crystallinity of the GO, PVA, crosslinked QPVA membrane and crosslinked QPVA/GO composite membranes. The illustrations of the diffraction pattern for the XRD analysis peak is present in Figure 2. Lee et al. (2014) reported that the crystallite peak of graphite was observed at $25.6^{\circ}$, while synthesized GO showed the progressive phase change from graphite to GO due to the crystallite peak appeared at new $2 \theta$ value which was at $10.92^{\circ}$. The peak of GO has high intensity at $10.92^{\circ}$ due to the interaction of hydrophobic $\mathrm{sp} 2$ region with the oxygen functional group of GO that has been produced through the oxidation process of graphite (Lee et al. 2014). The large peak at $19^{\circ}-20^{\circ}$ and the small peak at $39^{\circ}-40^{\circ}$ appeared were indicators of PVA spectra that the semi-crystalline structure of this polymer (Wang et al. 2010). After the quaternization process of PVA, the peak intensity of crosslinked QPVA membrane at $19^{\circ}-20^{\circ}$ has been decreased compared to pure
PVA. Introduction of ammonium function group has disturb the semi-crystalline structure of PVA polymer. This implies that the domain phase exist in the QPVA polymer matrix was the amorphous phase perhaps can enhance the ionic conductivity of the AEM. The amorphous phase contribute in facilitate the transport of anions in a polymer matrix by hopping mechanism between coordinate sites due to their less boundaries structure compared to the crystallite phase (Liao et al. 2015; Rajesh Kumar et al. 2015). After modification of matrix polymer QPVA with addition of GO, the large diffraction peak of GO was invisible, which indicates that GO is homogenously dispersed in the QPVA due to the physical interaction. Notably, the invisible GO peak at $2 \theta=10.92^{\circ}$ is due to the complete exfoliation and destruction of the regular stack by incorporation in QPVA. This result confirmed that the synthesis of a crosslinked QPVA/GO composite membrane was contribute by the formation of hydrogen bonding and the interactions at the ionic level between the polymer chains and the functional group in GO (Xue et al. 2014; Lin et al. 2017; Shaari \& Kamarudin 2017).

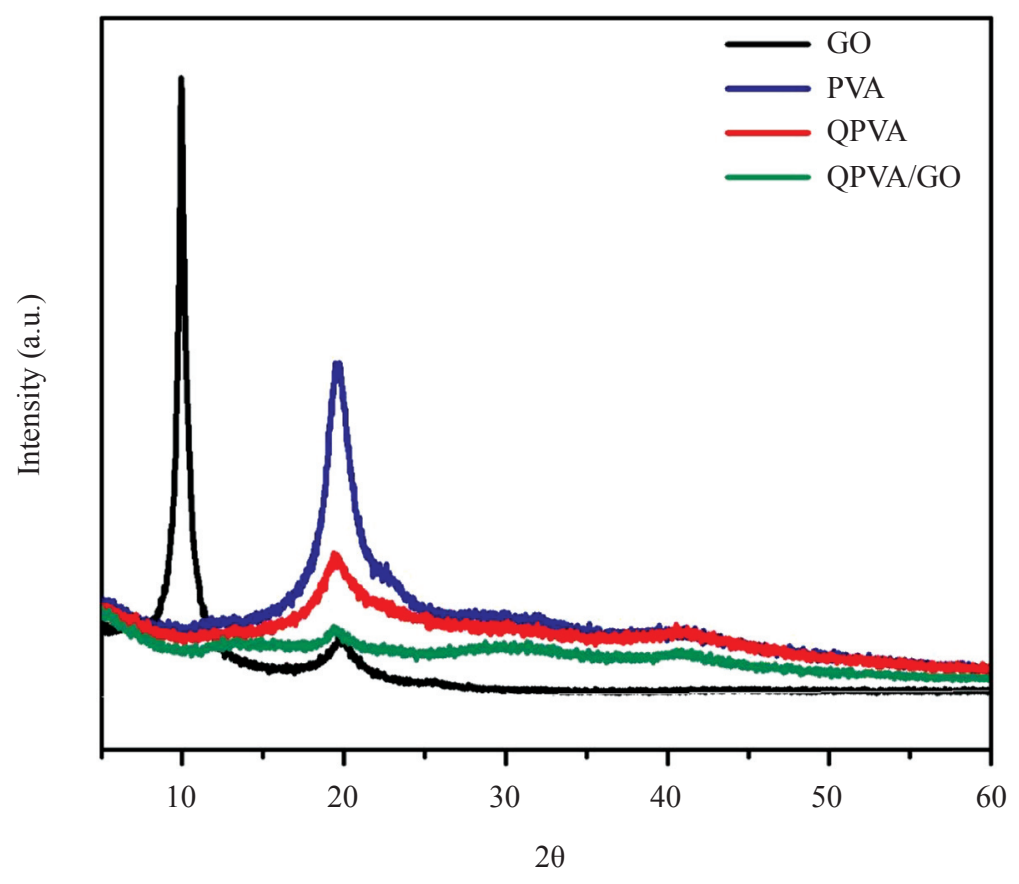

FIGURE 2. XRD spectra of GO, PVA film membrane, crosslinked QPVA membrane and crosslinked QPVA/GO composite membrane

Figure 3 present the FESEM image at a magnification of $100 \times$ for surface image and cross section image, respectively. All the membrane has produce the dense structure that useful for reduce the ethanol permeability issue. From the top view of FESEM photographs, the image reveal the crosslinked QPVA membrane in Figure 3(a) showed a few bulges presence, which attributed to the grafted aliphatic ammonium functional group and Figure 3(b) showed a compact and rugged texture (Ye et al. 2013). While the surface of QPVA/GO composite membrane looks homogeneous and smooth which might be due to the quaternary ammonium group has been grafted into polymer matrix. Besides, the random distribution of exfoliated GO throughout the electrolyte membrane also leads in dense membrane structure formation which required for electrolyte membrane. From the cross-sectional view in Figure 3(d), the composite membrane exhibit compact structure and high homogeneity, indicate that the unification of QPVA and GO in the composite membrane exist without any holes thus benefits for separation phenomena and reduce the ethanol permeability. Hence, the uniform distribution of exfoliated GO has improve the membrane performance (Xiong et al. 2008; Han et al. 2011). 


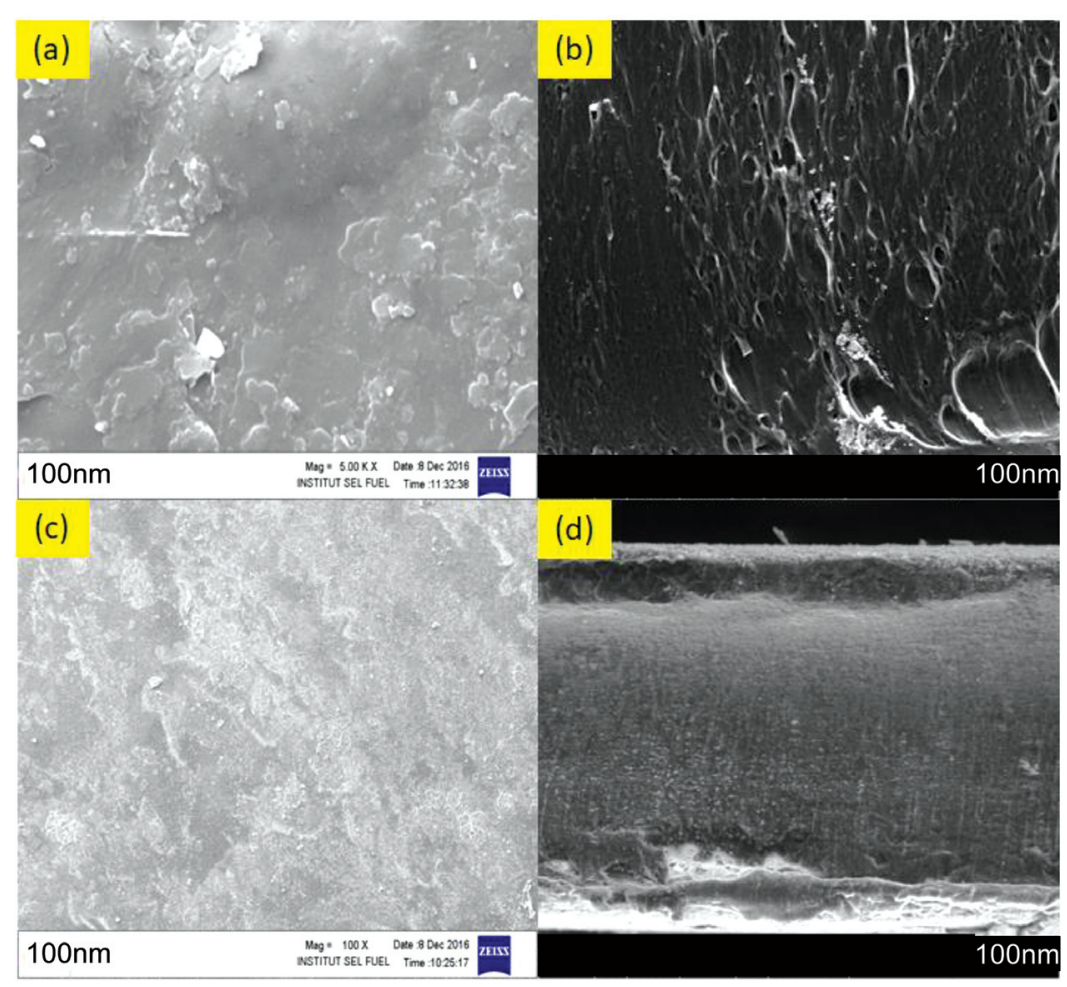

FIGURE 3. FESEM images of (a) QPVA membrane surface (b) QPVA membrane cross section, (c) crosslinked QPVA/GO membrane surface and (d) crosslinked QPVA/GO membrane cross section.

PERFORMANCE OF CROSSLINKED QPVA/GO COMPOSITE MEMBRANE

Figure 4 showed the ionic conductivity and ethanol permeability comparison of the QPVA membrane and crosslinked QPVA/GO composite membrane with 2 wt.\%, 4 wt. $\%, 6$ wt. $\%, 8$ wt. $\%$ and 10 wt. $\%$ loading of GO, respectively. After the crosslinking of membrane, all the membrane were soak in $2 \mathrm{M} \mathrm{KOH}$ solution for $24 \mathrm{~h}$ before all the samples stored in the deionized water to provide the alkaline electrolyte medium. From Figure 3, all membrane showed very low ethanol permeability which in range of $\times 10^{-7}$ $\mathrm{cm}^{2} \mathrm{~s}^{-1}$. This result prove that PVA based membrane has low fuel permeability due to their properties that low solubility in ethanol and it is the advantage in ethanol crossover issue (Saxena 2004). Subsequently, the modification of QPVA matrix with GO filler also leads in reducing the ethanol permeability.

The increasing of GO content in composite membranes has append the hydrophobic region which play role as blocking effect to hinder the ethanol crossover. This result proved that the exfoliation of GO provide three-dimensional network between GO, GA and QPVA which leads in compact structure formation as shown in FESEM images that show compact and dense structure, which consequently increasing the resistance to ethanol permeability. The lowest ethanol permeability was performed by crosslinked QPVA/GO $10 \mathrm{wt} . \%$ composite membrane of $2.2 \times 10^{-7} \mathrm{~cm}^{2} \mathrm{~s}^{-1}$ which was seven times better compared to Nafion 117 membrane $\left(1.95 \times 10^{-6}\right.$ $\mathrm{cm}^{2} \mathrm{~s}^{-1}$ ) (Leong et al. 2015; Lin et al. 2017).
Figure 4 also present the ionic conductivity of membrane. The introduced ammonium functional group has increased the ionic conductivity of PVA based membrane in range of $\times 10^{-2}$ $\mathrm{S} \mathrm{cm}^{-1}$ (Yang et al. 2014). Moreover, the introduction of GO loading was also successful enhance the ionic conductivity. The increasing in the ionic conductivity of the crosslinked QPVA/GO composite membrane was directly proportional to the increasing of GO loading from $0.52 \times 10^{-2} \mathrm{Scm}^{-1}$ for $2 \mathrm{wt} . \%$ to $1.08 \times 10^{-2} \mathrm{Scm}^{-1}$ for $10 \mathrm{wt} . \%$, respectively. The modification of QPVA with GO loading has provide the oxygenic functional group such as carboxyl, hydroxyl and epoxy which functions as anion pathways for hoping mechanism inside the electrolyte membrane. Besides, the strong interaction between GO, GA and QPVA has form three dimensional network that can hold water molecules in Grottus mechanism (Lin \& Lu 2013; Lee et al. 2014; Lin et al. 2017). However, this values is considered lower than Nafion 117 membrane that present conductivity until $7.5 \times 10^{-2} \mathrm{Scm}^{-1}$.

Figure 5 show the highest selectivity was presented by crosslinked QPVA/GO composite membrane with GO loading of $10 \mathrm{wt} . \%$. This composite membrane was selected for the further studies in single cell of passive alkaline-DEFC. The crosslinked QPVA/GO 10 wt.\% composite membranes selectivity was of $5.1 \times 10^{4} \mathrm{Ss} \mathrm{cm}^{-3}$ which higher than Nafion 117 of $3.84 \times 10^{4} \mathrm{Ss} \mathrm{cm}^{-3}$. Nafion 117 performed higher ionic conductivity compared to crosslinked QPVA/GO 10 wt.\% composite membranes, but, the ethanol permeability of crosslinked QPVA/GO 10 wt.\% composite membranes was more excellent compared to Nafion 117. Therefore, the selectivity of crosslinked QPVA/GO 10 wt.\% composite 


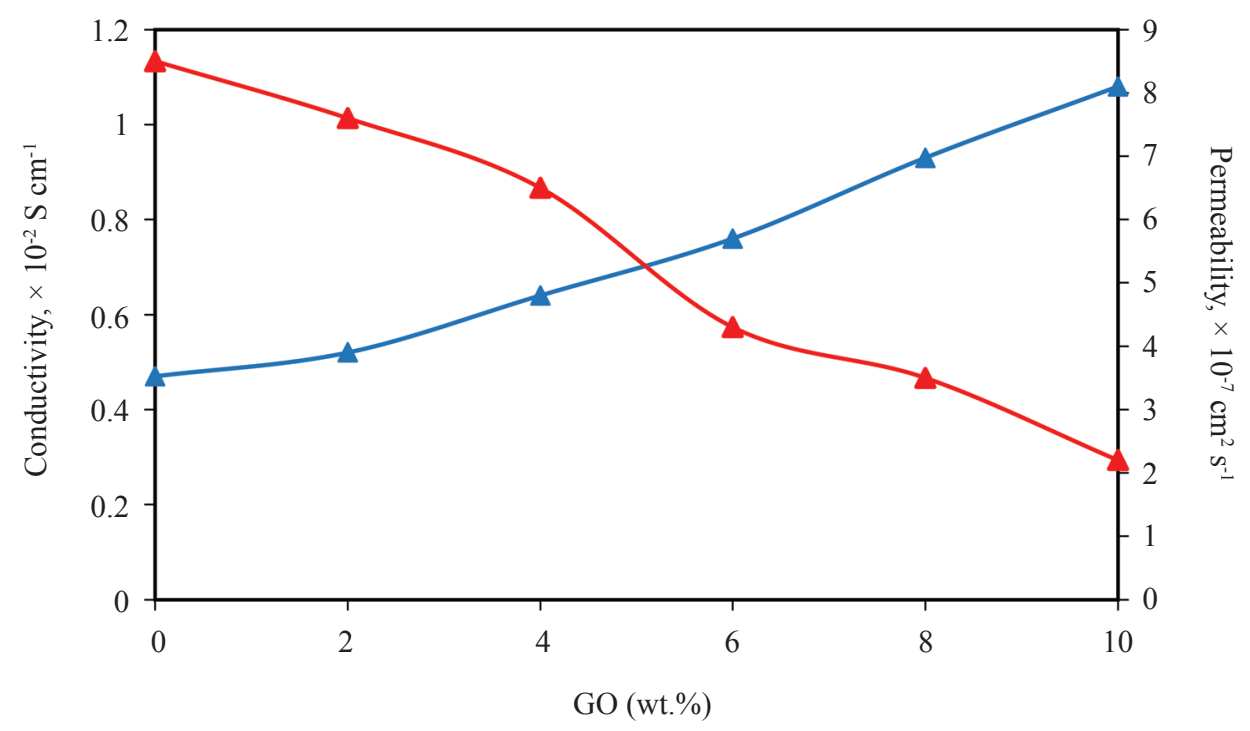

FIGURE 4. Ionic conductivity and ethanol permeability of QPVA membrane and crosslinked QPVA/GO composite membrane with different GO loading (wt.\%).

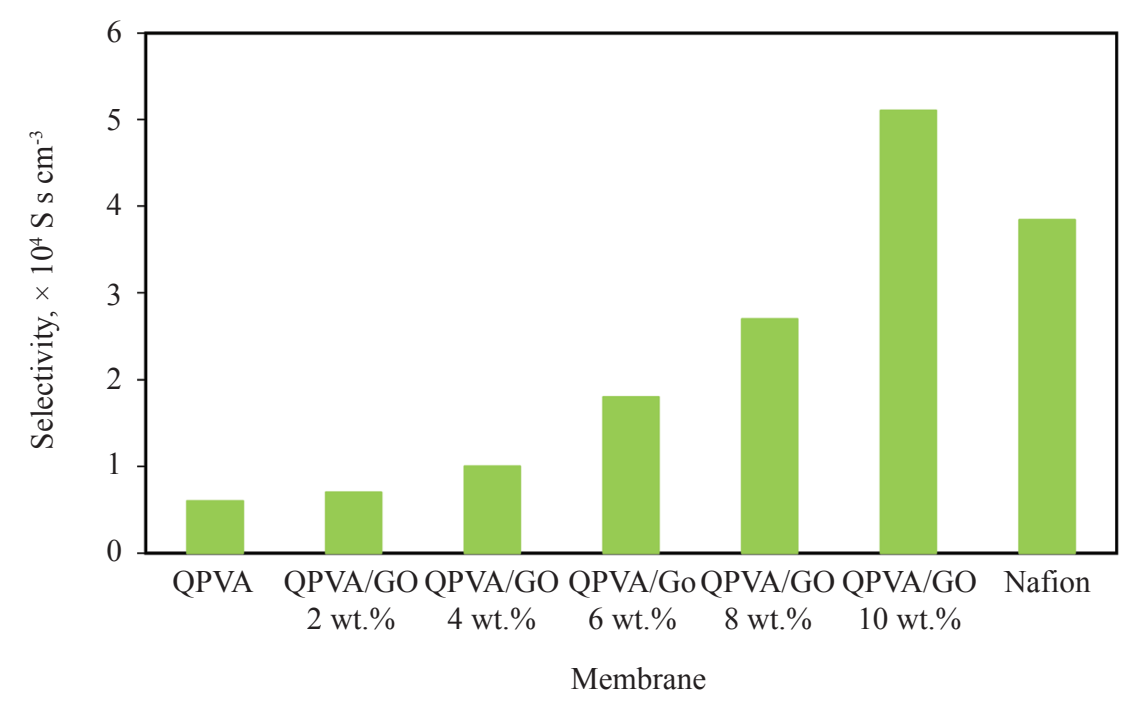

FIGURE 5. Selectivity membrane of QPVA membrane, crosslinked QPVA/GO composite membrane with different GO loading (wt.\%) and Nafion 117.

membranes higher than Nafion 117. As a hypothesis, the performance of passive alkaline - DEFC with crosslinked QPVA/GO 10 wt.\% composite membranes should be better than Nafion 117 (Thiam et al. 2013).

Figure 6 illustrates the cell voltage and power density vs current density curve of crosslinked QPVA/GO $10 \mathrm{wt} . \%$ composite membrane and Nafion 117 for passive alkalineDEFC at temperature $30^{\circ} \mathrm{C}$. Obviously this crosslinked QPVA/ GO 10 wt.\% composite membrane had reach an open-circuit voltage (OCV) of $0.47 \mathrm{~V}$ higher than Nafion 117 only of $0.42 \mathrm{~V}$ which attributed to the lower ethanol permeability of composite membrane compared to Nafion 117 (Yang et al. 2012). The value of OCV in this study was similar to the OCV value reported in previous study that used the passive cell for the single test performance which in the range of $0.4 \mathrm{~V}$ to $0.5 \mathrm{~V}$ (Esquivel et al. 2008; Zhao et al. 2010; Verjulio et al. 2014). The lower concentration of ethanol and $\mathrm{KOH}$ consumption can affect the OCV result. For the best result of $\mathrm{OCV}$, the concentration of ethanol and $\mathrm{KOH}$ used passive cell must be higher than $4 \mathrm{M}$ (Yuan et al. 2018). Verjulio et al. (2014) also reported that the OCV will be increased when the fuel concentration used increased.

A maximum power density of crosslinked QPVA/GO 10 wt.\% composite membrane was $6.92 \mathrm{~mW} \mathrm{~cm}^{-2}$ higher than Nafion 117 of $5.09 \mathrm{~mW} \mathrm{~cm}^{-2}$. The higher selectivity factor will give higher cell performance of single cell passive alkaline-DEFC. As a conclusion, this membrane has high potential to be developed in passive alkaline-DEFC. For the future works, we plan to enhance the $\mathrm{OH}^{-}$conduction with increase the loading of GO filler inside the QPVA matrix in order to increase the ionic conductivity and lowered the ethanol permeability. Optimistically, it leads in better performance of whole alkaline-DEFC systems. 


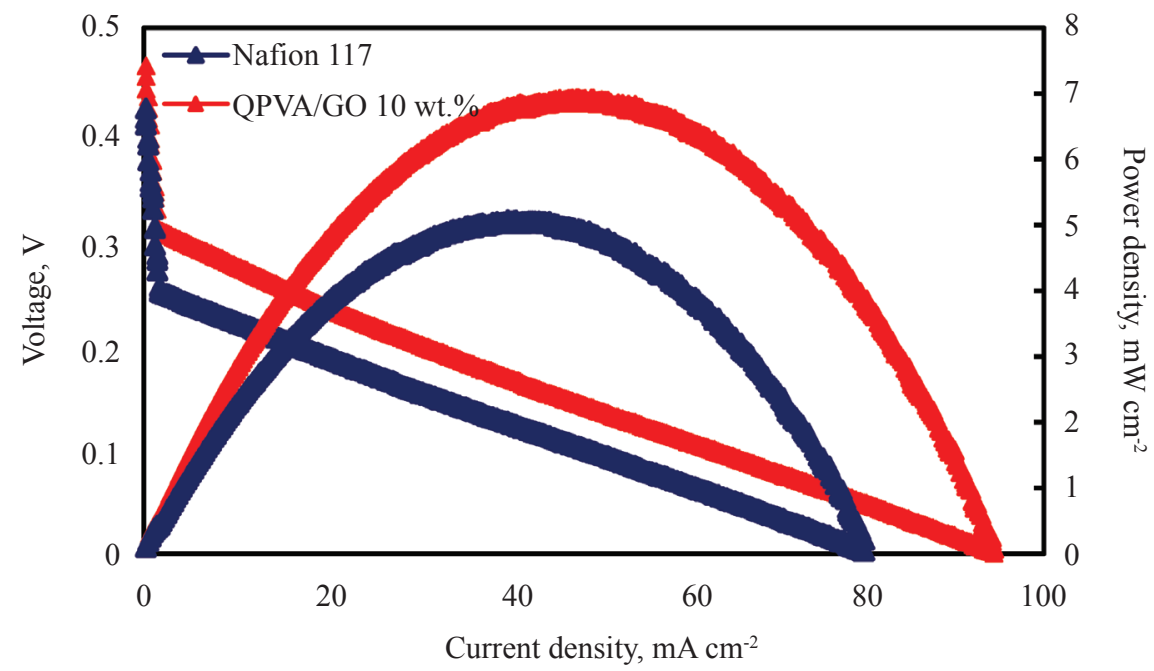

FIGURE 6. Cell voltage and power density vs current density curve of crosslinked QPVA/GO $10 \mathrm{wt} . \%$ composite membrane and Nafion $117\left(30^{\circ} \mathrm{C}\right.$ and $2 \mathrm{M}$ Ethanol $\left.+2 \mathrm{M} \mathrm{кон}\right)$.

\section{CONCLUSION}

The crosslinked QPVA/GO composite membrane was prepared for the passive alkaline-DEFC application. The presence of introduced quaternary ammonium group on PVA and existence of GO in polymer matrix was confirmed by FTIR and FESEM analysis. With the formation of three dimensional networking through reaction between QPVA polymer matrix, GO and GA cross-linked agent, the crosslinked QPVA/GO 10 wt.\% composite membrane show the highest ionic conductivity which achieve $1.08 \times 10^{-2} \mathrm{~S} \mathrm{~cm}^{-1}$ and their ethanol permeability show great reduction of $2.2 \times 10^{-7} \mathrm{~cm}^{2} \mathrm{~s}^{-1}$ compared to the Nafion 117 membranes that only performed about $1.95 \times$ $10^{-6} \mathrm{~cm}^{2} \mathrm{~s}^{-1}$ at room temperature. The membrane with highest selectivity which crosslinked QPVA/GO $10 \mathrm{wt} . \%$ composite membrane is further test in single cell part and it achieved maximum power density of $6.92 \mathrm{mWcm}^{-2}$ which higher than Nafion 117 of $5.09 \mathrm{~mW} \mathrm{~cm}^{-2}$ at $30^{\circ} \mathrm{C}$. Therefore, the crosslinked QPVA/GO composite membrane has high potential to be apply and performed in DEFCs system in future.

\section{ACKNOWLEDGEMENT}

The authors gratefully acknowledge the financial support given for this work by the Universiti Kebangsaan Malaysia (UKM) under DIP-2015-002 and MyPhD form Kementerian Pengajian Tinggi, Malaysia.

REFERENCES

Akhairi, M. \& Kamarudin, S. K. 2016. Catalysts in direct ethanol fuel cell (DEFC): An overview. International Journal of Hydrogen Energy 41(7): 4214-4228.

An, L. \& Zhao, T. 2017. Transport phenomena in alkaline direct ethanol fuel cells for sustainable energy production. Journal of Power Sources 341: 199-211.

An, L., Zhao, T. \& Li, Y. 2015. Carbon-neutral sustainable energy technology: direct ethanol fuel cells. Renewable and Sustainable Energy Reviews 50: 1462-1468.
Badwal, S., Giddey, S., Kulkarni, A., Goel, J. \& Basu, S. 2015. Direct ethanol fuel cells for transport and stationary applications-A comprehensive review. Applied Energy 145: 80-103.

Cao, Y.-C., Xu, C., Wu, X., Wang, X., Xing, L. \& Scott, K. 2011. A poly (ethylene oxide)/graphene oxide electrolyte membrane for low temperature polymer fuel cells. Journal of Power Sources 196(20): 8377-8382.

de Souza Gomes, A. \& Dutra Filho, J. C. 2012. Hybrid membranes of PVA for direct ethanol fuel cells (DEFCs) applications. International Journal of Hydrogen Energy 37(7): 6246-6252.

Esquivel, J., Sabaté, N., Santander, J., Torres, N. \& Cané, C. 2008. Fabrication and characterization of a passive silicon-based direct methanol fuel cell. Microsystem Technologies 14(4-5): 535-541.

Farooqui, U., Ahmad, A. \& Hamid, N. 2018. Graphene oxide: A promising membrane material for fuel cells. Renewable and Sustainable Energy Reviews 82: 714-733.

Gu, S., He, G., Wu, X., Guo, Y., Liu, H., Peng, L. \& Xiao, G. 2008. Preparation and characteristics of crosslinked sulfonated poly (phthalazinone ether sulfone ketone) with poly (vinyl alcohol) for proton exchange membrane. Journal of Membrane Science 312(1): 48-58.

Han, D., Yan, L., Chen, W. \& Li, W. 2011. Preparation of chitosan/graphene oxide composite film with enhanced mechanical strength in the wet state. Carbohydrate Polymers 83(2): 653-658.

Huang, C.-Y., Lin, J.-S., Pan, W.-H., Shih, C.-M., Liu, Y.-L. \& Lue, S. J. 2016. Alkaline direct ethanol fuel cell performance using alkali-impregnated polyvinyl alcohol/ functionalized carbon nano-tube solid electrolytes. Journal of Power Sources 303: 267-277.

Karim, M. R., Islam, M. S., Hatakeyama, K., Nakamura, M., Ohtani, R., Koinuma, M. \& Hayami, S. 2016. Effect of interlayer distance and oxygen content on proton conductivity of graphite oxide. The Journal of Physical Chemistry C 120(38): 21976-21982. 
Lee, D., Yang, H., Park, S. \& Kim, W. 2014. Nafion/graphene oxide composite membranes for low humidifying polymer electrolyte membrane fuel cell. Journal of Membrane Science 452: 20-28.

Leong, J. X., Daud, W. R. W., Ghasemi, M., Ahmad, A., Ismail, M. \& Liew, K. B. 2015. Composite membrane containing graphene oxide in sulfonated polyether ether ketone in microbial fuel cell applications. International Journal of Hydrogen Energy 40(35): 11604-11614.

Liao, G.-M., Yang, C.-C., Hu, C.-C., Pai, Y.-L. \& Lue, S. J. 2015. Novel quaternized polyvinyl alcohol/quaternized chitosan nano-composite as an effective hydroxideconducting electrolyte. Journal of Membrane Science 485: 17-29.

Lin, C. \& Lu, Y. 2013. Highly ordered graphene oxide paper laminated with a Nafion membrane for direct methanol fuel cells. Journal of Power Sources 237: 187-194.

Lin, J.-S., Kumar, S. R., Ma, W.-T., Shih, C.-M., Teng, L.-W., Yang, C.-C. \& Lue, S. J. 2017. Gradiently distributed iron oxide@ graphene oxide nanofillers in quaternized polyvinyl alcohol composite to enhance alkaline fuel cell power density. Journal of Membrane Science 543: 28-39.

Lo, C.-F., Wu, J.-F., Li, H.-Y., Hung, W.-S., Shih, C.-M., Hu, C.-C., Liu, Y.-L. \& Lue, S. J. 2013. Novel polyvinyl alcohol nanocomposites containing carbon nano-tubes with $\mathrm{Fe} 3 \mathrm{O} 4$ pendants for alkaline fuel cell applications. Journal of Membrane Science 444: 41-49.

O'hayre, R., Cha, S.-W., Prinz, F. B. \& Colella, W. 2016. Fuel cell fundamentals Ed.: John Wiley \& Sons.

Rajesh Kumar, S., Juan, C.-H., Liao, G.-M., Lin, J.-S., Yang, C.-C., Ma, W.-T., You, J.-H. \& Jessie Lue, S. 2015. Fumed silica nanoparticles incorporated in quaternized poly (vinyl alcohol) nanocomposite membrane for enhanced power densities in direct alcohol alkaline fuel cells. Energies 9(1): 15.

Saxena, S. 2004. Polyvinyl alcohol (PVA). Chemical and Technical Assessment (CTA) 61: 3-7.

Shaari, N. \& Kamarudin, S. 2017. Graphene in electrocatalyst and proton conductiong membrane in fuel cell applications: An overview. Renewable and Sustainable Energy Reviews 69: 862-870.

Thiam, H., Daud, W. R. W., Kamarudin, S. K., Mohamad, A. B., Kadhum, A. A. H., Loh, K. S. \& Majlan, E. 2013. Nafion/Pd-SiO 2 nanofiber composite membranes for direct methanol fuel cell applications. International Journal of Hydrogen Energy 38(22): 9474-9483.

Verjulio, R., Santander, J., Sabaté, N., Esquivel, J., TorresHerrero, N., Habrioux, A. \& Alonso-Vante, N. 2014. Fabrication and evaluation of a passive alkaline membrane micro direct methanol fuel cell. International Journal of Hydrogen Energy 39(10): 5406-5413.

Wang, E., Zhao, T. \& Yang, W. 2010. Poly (vinyl alcohol)/3(trimethylammonium) propyl-functionalized silica hybrid membranes for alkaline direct ethanol fuel cells. International Journal of Hydrogen Energy 35(5): 2183 2189.

Xiong, Y., Fang, J., Zeng, Q. H. \& Liu, Q. L. 2008. Preparation and characterization of cross-linked quaternized poly (vinyl alcohol) membranes for anion exchange membrane fuel cells. Journal of Membrane Science 311(1): 319-325.

Xue, C., Zou, J., Sun, Z., Wang, F., Han, K. \& Zhu, H. 2014. Graphite oxide/functionalized graphene oxide and polybenzimidazole composite membranes for high temperature proton exchange membrane fuel cells. International Journal of Hydrogen Energy 39(15): 7931-7939.

Yang, C.-C., Chiu, S.-S., Kuo, S.-C. \& Liou, T.-H. 2012. Fabrication of anion-exchange composite membranes for alkaline direct methanol fuel cells. Journal of Power Sources 199: 37-45.

Yang, J.-M., Wang, N.-C. \& Chiu, H.-C. 2014. Preparation and characterization of poly (vinyl alcohol)/sodium alginate blended membrane for alkaline solid polymer electrolytes membrane. Journal of Membrane Science 457: 139-148.

Ye, L., Zhai, L., Fang, J., Liu, J., Li, C. \& Guan, R. 2013. Synthesis and characterization of novel cross-linked quaternized poly (vinyl alcohol) membranes based on morpholine for anion exchange membranes. Solid State Ionics 240: 1-9.

Yuan, W., Han, F., Chen, Y., Chen, W., Hu, J. \& Tang, Y. 2018. Enhanced water management and Fuel Efficiency of a Fully Passive Direct Methanol Fuel Cell with superhydrophilic/-hydrophobic cathode porous flow-field. Journal of Electrochemical Energy Conversion and Storage 15(3): 031003.

Zakaria, Z., Kamarudin, S. K. \& Timmiati, S. 2016. Membranes for direct ethanol fuel cells: an overview. Applied Energy 163: 334-342.

Zeng, L., Zhao, T. \& Li, Y. 2012. Synthesis and characterization of crosslinked poly (vinyl alcohol)/layered double hydroxide composite polymer membranes for alkaline direct ethanol fuel cells. International Journal of Hydrogen Energy 37(23): 18425-18432.

Zhao, T., Li, Y. \& Shen, S. 2010. Anion-exchange membrane direct ethanol fuel cells: Status and perspective. Frontiers of Energy and Power Engineering in China 4(4): 443458.

*Zulfirdaus Zakaria

Norazuwana Shaari

Institute of Fuel Cell,

Universiti Kebangsaan Malaysia, Malaysia

Siti Kartom Kamarudin

Institute of Fuel Cell,

Universiti Kebangsaan Malaysia, Malaysia

Department of Chemical Engineering \& Process

Faculty of Engineering \& Built Environment

Universiti Kebangsaan Malaysia, Malaysia.

*Corresponding author; email: zulfirdauszakaria@gmail.com

Received date: $9^{\text {th }}$ April 2018

Accepted date: $14^{\text {th }}$ July 2018

Online first date: $1^{\text {st }}$ September 2018

Published date: $31^{\text {st }}$ October 2018 